\title{
Biochemical study on immunomodulation and safety margin of inosine acedoben dimepranol before and after vaccination
}

\author{
Abdel Maksoud Hussein *, Omnia Mahmoud and Mahmoud Khalifa \\ Department of Biochemistry, Benha University, Egypt.
}

Publication history: Received on 14 October 2019; revised on 09 November 2019; accepted on 13 November 2019

Article DOI: https://doi.org/10.30574/gscarr.2019.1.1.0008

\begin{abstract}
The aim of this study was to evaluate the immunopotentiating effect of IAD in broiler chickens either vaccinated or unvaccinated and to evaluate the safety profile of IAD after treatment with escalating doses. To assess the immunological effect of IAD, eighty chicks were used and divided into four groups. First group kept as control group, second received Isoprinosine $(16.3 \mathrm{mg} / \mathrm{kg}$, day after day), third received a routine New Castle disease virus vaccine and the last group received both treatments of Isoprinosine and ND vaccine. The second part of the study aimed to evaluate the safety profile of IAD, to achieve this aim eighty chicks were used, divided equally and given different concentration of IAD $8.15,16.3,32.6 \mathrm{mg} / \mathrm{kg}$ day after day repetitively. We concluded that, IAD enhanced both nonspecific and specific immune responses in broiler chicken, especially in vaccinated ones, in terms of increased antibody and decreased NDV titers, indicated by HI and PCR, respectively. Also, IAD showed dose-dependent good safety profile, including blood picture, organ function profile and metabolic parameters, indicated by biochemical analyses.
\end{abstract}

Keywords: IAD; ND vaccine; Safety profile

\section{Introduction}

Poultry industry is considered as one of the most important fields in veterinary practice for human livelihood. Farming poultry without immune umbrella may expose them to variety of diseases, especially viral respiratory ones, with consequent big losses and health hazards. Therefore, farmers always follow strict vaccination programs and try to enhance immunological status of their flocks by all means. Drink and feed additives as immune enhancers are of particular concern in this respect [1]

Inosine Acedoben Dimepranol (IAD, Isoprenosine ${ }^{\circledR}$ ) is a synthetic purine derivative, composed of the pacetamidobenzoate salt of $\mathrm{N}$, N-dimethylamino-2-propanol and inosine at a 3:1 molar ratio which provides a unique double therapeutic benefits. Namely, it exerts antiviral effects [2] and immunomodulatory activities [3], on the other hand. It also used for treatment of Leishmania major infection, multiple sclerosis, Echinococcus multilocularis and Echinococcus granulosus metacestodes, neurodegeneration, cancer and alopecia [4].

IAD is being used in human medical practice in many countries for potentiating immunity with multifunction outcomes. However, it is not tried in the veterinary practice despite its considerable impacts. Introducing drugs into the Veterinary field necessitates two essential needs, namely efficacy and safety. After proving a drug to be effective, if any, evaluating its safety profile in certain species becomes a must [5].

\footnotetext{
${ }^{*}$ Corresponding author

E-mail address: $\underline{\mathrm{hm} 2243049 @ g m a i l . c o m}$
} 
Therefore, the present study was designed to evaluate the immunopotentiating potential of IAD in broiler chickens either vaccinated or unvaccinated; and to evaluate the safety profile of IAD in broiler chicks after treatment with escalating doses.

\section{Material and methods}

\subsection{Preparation of isoprinosine}

The dosage range for human is $50 \sim 100 \mathrm{mg} /$ day, orally, according to the severity of the condition. The average dose prescribed for human (50 mg/day) in 3-4 divided dose was converted to equivalent dose for poultry according to [6] The poultry dose was calculated as $163 \mathrm{mg} / \mathrm{kg}$. Body weight. Thus, a chick weighing $100 \mathrm{~g}$ received a daily dose of 16.3 $\mathrm{mg} /$ day in drinking water for immunity test. For safety study, additional two doses (Low dose $8.15 \mathrm{mg} / \mathrm{day}$ and high dose $32.6 \mathrm{mg}$ /day) were applied.

\subsection{Laboratory animals}

One hundred and twenty (120) Cobb-500, a day old chicks of approximate weights 100 g were used in this study. Chicks were kept in separate partitions and allowed to a plenty of water and diets at temperature 31-33ㄷ‥According to ethical approval committee in Benha University. After one week of acclimatization, chick received different treatments as will be mentioned in the study design.

\subsection{Experimental design}

Acclimatized chicks were used in two separate experiments in a parallel study design.

\subsection{Experiment-1 (Immunological study)}

Eighty chicks were divided into 4 groups, each consists of 20 chicks, to assess the immunological effect of Isoprinosine. The groups were treated differently as follows:

GROUP I: chicks were kept on normal conditions of water and feed; and received no drugs; kept as control. GROUP II: chicks received Isoprinosine $(16.3 \mathrm{mg} / \mathrm{kg}$, day after day) in drinking water; kept as drug only group. GROUP III: chicks received a routine New Castle disease virus vaccine (Hitchner and Lasota) in drinking water, according to instructions of the manufacturer; kept as vaccine only group.

GROUP IV: chicks received both treatments of Isoprinosine and ND vaccine; kept as drug and vaccine group.

\subsection{Sampling}

Two types of blood samples were collected. Blood for total and differential leukocytic counts on the $21^{\text {th }}$ and $42^{\text {nd }}$ days from the start of the experiment. Blood for serum was collected on the same time points for determination of antibody titer of ND virus using hemagglutination (HA) and haemagglutination inhibition (HI) tests. Samples were collected from the medial metatarsal vein by means of $3 \mathrm{ml}$ syringe with 20G needle. The collected blood was allowed to clot at room temperature for an hour; and then refrigerated for further an hour for clot retraction. Clear sera were separated by centrifugation at 3000 r.p.m. for 10 minutes and then collected in Eppendrof's tubes using automatic pipettes. Serum samples were kept in deep freezer $\left(-20^{\circ} \mathrm{C}\right.$.) till analysis.

After blood sampling, 5 chicks of each group were sacrificed and the brain, proventriculous, lung with bronchi and intestine were taken in saline for quantitation of ND antigen by using PCR.

The remaining 60 chicks (15/group) were subjected to challenge test as described later.

\subsection{Experiment-2 (safety study)}

Forty chicks were divided into 4 groups, each consists of 10 chicks, to assess the safety of Isoprinosine. The groups were treated differently as follows:

GROUP I : chicks were kept on normal conditions of water and feed; and received no drug; kept as control. GROUP II : chicks received Isoprinosine $(8.15 \mathrm{mg} / \mathrm{kg}$, day after day) in drinking water; kept as low dose group. GROUP III : chicks received Isoprinosine $(16.3 \mathrm{mg} / \mathrm{kg}$, day after day) in drinking water; kept as normal dose group. GROUP IV : chicks received Isoprinosine $(32.6 \mathrm{mg} / \mathrm{kg}$, day after day) in drinking water; kept as high dose group. 


\subsection{Sampling}

Two types of blood samples were collected. Blood for haemogram (erythrogram and leuckogram).On the $21^{\text {th }}$ and $42^{\text {nd }}$ days from the start of the experiment. Blood for serum was collected on the same time points for measurement of Total Protein, Albumin (ALB), Globulin (GLB), Bilirubin (BIL), Aspartate aminotransferase (AST), Alanine aminoransferase (ALT), Urea (URE), Creatinine (CRE), Uric Acid (UAC), Glucose (GLU), Total cholesterol, Triacylglycerol (TAG) and Lipoproteins (LDL-C,VLDL-C,HDL-C). Samples were collected from the medial metatarsal vein by means of $3 \mathrm{ml}$ syringe with 20G needle. The collected blood was allowed to clot at room temperature for an hour; and then refrigerated for further an hour for clot retraction. Clear sera were separated by centrifugation at 3000 r.p.m. for 10 minutes and then collected in Eppendrof's tubes using automatic pipettes. Serum samples were kept in deep freezer $\left(-20^{\circ} \mathrm{C}\right.$.) till analysis.

\section{Results}

Table 1 Effects of IAD on differential leukocytic counts

\begin{tabular}{|c|c|c|c|c|c|c|c|c|}
\hline \multirow{2}{*}{$\begin{array}{l}\text { Groups } \\
\text { Duration }\end{array}$} & \multicolumn{2}{|l|}{ Control } & \multicolumn{2}{|l|}{ IAD only } & \multicolumn{2}{|c|}{ Vaccine only } & \multicolumn{2}{|c|}{ IAD+vaccine } \\
\hline & 21 DAY & $42 \mathrm{DAY}$ & 21 DAY & $42 \mathrm{DAY}$ & 21 DAY & $42 \mathrm{DAY}$ & 21 DAY & 42 DAY \\
\hline Total & $\begin{array}{l}20.8 \pm 1.18^{a b c} \\
d\end{array}$ & $\begin{array}{l}21.8 \pm 1.44^{\mathrm{abc}} \\
\mathrm{d}\end{array}$ & $\begin{array}{l}27.2 \pm 1.46^{\text {ba }} \\
\text { d }\end{array}$ & $\begin{array}{l}40 \pm 1.18^{\text {ba }} \\
\text { d }\end{array}$ & $\begin{array}{l}29.2 \pm 1.37 \text { ca } \\
\text { d }\end{array}$ & $44 \pm 4.36^{\mathrm{cad}}$ & $\begin{array}{l}31.2 \pm 1.39 \mathrm{dab} \\
\mathrm{c}\end{array}$ & $\begin{array}{l}53.2 \pm 1.37 \mathrm{dab} \\
\mathrm{c}\end{array}$ \\
\hline $\begin{array}{l}\text { Granulocyt } \\
\text { e }\end{array}$ & $12.18 \pm 0.15^{\mathrm{a}}$ & $12.5 \pm 0.6^{\mathrm{a}}$ & $16.3 \pm 0.65^{b}$ & $\begin{array}{l}23.6 \pm 0.52 \\
b\end{array}$ & $15 \pm 0.68^{c}$ & $19 \pm 0.89 \mathrm{c}$ & $15.6 \pm 0.77^{d}$ & $24.6 \pm 1.05^{\mathrm{d}}$ \\
\hline Monocyte & $3.72 \pm 0.2^{\mathrm{a}}$ & $3.64 \pm 0.05^{\mathrm{a}}$ & $4.6 \pm 0.38^{b}$ & $7.4 \pm 0.68^{b}$ & $4.24 \pm 0.35^{c}$ & $7.04 \pm 1.32^{\mathrm{c}}$ & $6.2 \pm 0.5^{\mathrm{d}}$ & $10 \pm 0.52^{\mathrm{d}}$ \\
\hline $\begin{array}{l}\text { Lymphocyt } \\
\text { e }\end{array}$ & $\begin{array}{l}4.24 \pm 0.06^{\mathrm{abc}} \\
\mathrm{d}\end{array}$ & $4.3 \pm 0.11_{\mathrm{abcd}}$ & $6.28 \pm 0.7^{\mathrm{bad}}$ & $9 \pm 0.68^{\mathrm{bad}}$ & $\begin{array}{l}9.96 \pm 0.98^{\text {ca }} \\
\text { d }\end{array}$ & ${ }_{\mathrm{d}}^{15.1 \pm 1.71^{\mathrm{ca}}}$ & $9.4 \pm 0.83^{\mathrm{dabc}}$ & $\begin{array}{l}18.6 \pm 1.83^{\text {dab }} \\
\text { c }\end{array}$ \\
\hline
\end{tabular}

Data with different superscript letters (a,b,c,d) indicate significant difference $(P \leq 0.05)$.

Table 2 PCR titer in lung, trachea and intestine in different groups post challenge

\begin{tabular}{llllll}
\hline $\begin{array}{l}\text { Sample } \\
\text { No. }\end{array}$ & Sample ID & Groups & Result & CT & $\begin{array}{l}\text { Titer } \\
\text { (EID50/ml) }\end{array}$ \\
\hline 1 & Lung + Trachea & Control & + & 19.25 & $7.259 \times 10^{6} \mathrm{abcd}$ \\
1 & Intestine & & + & 20.67 & $2.718 \times 10^{6} \mathrm{abcd}$ \\
2 & Lung + Trachea & IAD & + & 22.54 & $7.456 \times 10^{5} \mathrm{bacd}$ \\
2 & Intestine & vaccine & + & 23.88 & $2.951 \times 10^{5} \mathrm{bacd}$ \\
3 & Lung + Trachea & Vaccine & + & 27.19 & $2.989 \times 10^{4}$ cabd \\
3 & Intestine & only & + & 25.31 & $10.97 \times 10^{4}$ cabd \\
4 & Lung + Trachea & & + & - & - dabc \\
4 & Intestine & & + & 28.36 & $1.331 \times 10^{4}$ dabc \\
\hline
\end{tabular}

Table 3 Mean Log2 HI serum antibody titer of groups before and after challenge test

\begin{tabular}{|c|c|c|c|c|}
\hline Groups & control & $\begin{array}{l}\text { IAD } \\
\text { only }\end{array}$ & $\begin{array}{l}\text { vaccine } \\
\text { only }\end{array}$ & IAD+vaccine \\
\hline $\begin{array}{l}\text { Mean log2 HI serum antibody titer on day } 42 \text { before } \\
\text { challenge test }\end{array}$ & 0.00 & 0.00 & $3 \pm 0.33 *$ & $9.5 \pm 0.56 *$ \\
\hline Protection $\%$ after challenge test $(n=15)$ & $0 \%$ & $25 \%$ & $50 \%$ & $75 \%$ \\
\hline $\begin{array}{l}\text { Mean } \log 2 \text { HI serum antibody titer } 7 \text { days after challenge } \\
\text { test }\end{array}$ & $\begin{array}{l}\text { Not } \\
\text { survived }\end{array}$ & $9.5 *$ & $>11 *$ & $>11 *$ \\
\hline
\end{tabular}


Table 4 Effects of IAD at different dose on hemogram

\begin{tabular}{|c|c|c|c|c|c|c|c|c|}
\hline \multirow{2}{*}{$\frac{\text { Groups }}{\text { Duration }}$} & \multicolumn{2}{|l|}{ CONTROL } & \multicolumn{2}{|c|}{ IAD (8.15 MG/KG) } & \multicolumn{2}{|c|}{ IAD (16.3 MG/KG) } & \multicolumn{2}{|c|}{ IAD (32.6 MG/KG) } \\
\hline & $21 \mathrm{DAY}$ & $42 \mathrm{DAY}$ & $21 \mathrm{DAY}$ & $42 \mathrm{DAY}$ & $21 \mathrm{DAY}$ & 42 DAY & $21 \mathrm{DAY}$ & $42 \mathrm{DAY}$ \\
\hline $\begin{array}{l}\text { Hemoglobin } \\
(\mathrm{g} / \mathrm{dl})\end{array}$ & $23.32 \pm 0.98 \mathrm{a}$ & $15.875 \pm 1.5^{\mathrm{a}}$ & $18.44 \pm 0.09 \mathrm{~b}$ & $14.3 \pm 0.55 \mathrm{~b}$ & $20.54 \pm 0.36^{c}$ & $13.03 \pm 0.24 \mathrm{c}$ & $21.53 \pm 0.08 \mathrm{~d}$ & $14.57 \pm 1.02 \mathrm{~d}$ \\
\hline $\begin{array}{l}\text { Red cell count } \\
\left(\mathrm{x} 10^{12} / \mathrm{L}\right)\end{array}$ & $8.05 \pm 0.32 \mathrm{a}$ & $5.45 \pm 0.52 \mathrm{a}$ & $6.33 \pm 0.25 b$ & $4.9 \pm 0.19 b$ & $7.08 \pm 0.13 c$ & $4.43 \pm 0.05 \mathrm{c}$ & $7.43 \pm 0.05 \mathrm{~d}$ & $4.95 \pm 0.36 \mathrm{~d}$ \\
\hline $\begin{array}{l}\text { Packed cell volume } \\
(\%)\end{array}$ & $67.40 \pm 2.83 \mathrm{a}$ & $45.82 \pm 4.31 \mathrm{a}$ & $53.33 \pm 0.23 b$ & $41.3 \pm 1.59 b$ & $59.38 \pm 1.03^{c}$ & $37.98 \pm 1.03 \mathrm{c}$ & $62.18 \pm 0.23 \mathrm{~d}$ & $42.48 \pm 2.84 \mathrm{~d}$ \\
\hline $\operatorname{MCV}(f l)$ & $83.77 \pm 0.13 \mathrm{a}$ & $84.15 \pm 0.32 \mathrm{a}$ & $84.34 \pm 0.02 b$ & $84.3 \pm 0.22 b$ & $83.93 \pm 0.03^{c}$ & $85.80 \pm 1.61^{c}$ & $83.5 \pm 0.04 \mathrm{~d}$ & $85.93 \pm 1.58 \mathrm{~d}$ \\
\hline MCH (pg) & $28.95 \pm 0.03 \mathrm{a}$ & $29.10 \pm 0.12^{a}$ & $29.13 \pm 0.03 \mathrm{~b}$ & $29.2 \pm 0.13 b$ & $29.01 \pm 0.01 \mathrm{c}$ & $29.38 \pm 0.28^{c}$ & $28.83 \pm 0.03 \mathrm{~d}$ & $29.43 \pm 0.28 \mathrm{~d}$ \\
\hline $\mathrm{MCHC}(\mathrm{g} / \mathrm{dl})$ & $34.55 \pm 0.05^{\mathrm{a}}$ & $34.60 \pm 0$ a & $33.95 \pm 0.22 b$ & $34.6 \pm 0.00 \mathrm{~b}$ & $34.38 \pm 0.03 \mathrm{c}$ & $34.23 \pm 0.31^{c}$ & $34.45 \pm 0.05 \mathrm{~d}$ & $34.28 \pm 0.33 \mathrm{~d}$ \\
\hline WBCs $\left(\times 10^{9} / \mathrm{L}\right)$ & $20.8 \pm 1.18 \mathrm{abcd}$ & $21.8 \pm 1.44 \mathrm{abcd}$ & $19.6 \pm 1.2 \mathrm{bad}$ & $33.25 \pm 2.31 \mathrm{bad}$ & $27.2 \pm 1.46 \mathrm{cad}$ & $40 \pm 1.18 \mathrm{cad}$ & $34.8 \pm 0.85$ dabc & $47.6 \pm 1.18 \mathrm{dabc}$ \\
\hline
\end{tabular}

Table 5 Effects of IAD at different dose on liver function parameters

\begin{tabular}{|c|c|c|c|c|c|c|c|c|}
\hline \multirow{2}{*}{$\begin{array}{l}\text { Groups } \\
\text { Duration }\end{array}$} & \multicolumn{2}{|l|}{ CONTROL } & \multicolumn{2}{|c|}{ IAD (8.15 MG/KG) } & \multicolumn{2}{|c|}{ IAD (16.3 MG/KG) } & \multicolumn{2}{|c|}{ IAD (32.6 MG/KG) } \\
\hline & $21 \mathrm{DAY}$ & $42 \mathrm{DAY}$ & $21 \mathrm{DAY}$ & 42 DAY & $21 \mathrm{DAY}$ & 42 DAY & $21 \mathrm{DAY}$ & $42 \mathrm{DAY}$ \\
\hline Total protein & $3.0 \pm 0.08$ ad & $3.4 \pm 0.39$ acd & $3.18 \pm 0.33 \mathrm{bd}$ & $4.02 \pm 0.3 \mathrm{bd}$ & $3.33 \pm 0.23 c$ & $4.41 \pm 0.41$ са & $3.94 \pm 0.23$ dab & $5.1 \pm 0.27 \mathrm{dab}$ \\
\hline Albumin & $1.46 \pm 0.09 \mathrm{a}$ & $1.65 \pm 0.03^{a}$ & $1.48 \pm 0.13 b$ & $1.59 \pm 0.02 \mathrm{~b}$ & $1.5 \pm 0.07 \mathrm{c}$ & $1.67 \pm 0.06^{c}$ & $1.59 \pm 0.2 \mathrm{~d}$ & $1.77 \pm 0.03 \mathrm{~d}$ \\
\hline Globulin & $1.54 \pm 0.04 \mathrm{ad}$ & $1.75 \pm 0.38 \mathrm{acd}$ & $1.7 \pm 0.35 \mathrm{bd}$ & $2.43 \pm 0.31 \mathrm{bd}$ & $1.83 \pm 0.22 c$ & $2.75 \pm 0.37$ са & $2.35 \pm 0.32$ dab & $3.33 \pm 0.26$ dab \\
\hline AST (U/L) & $173.02 \pm 13.67 \mathrm{a}$ & $272.82 \pm 20.44 \mathrm{a}^{\mathrm{a}}$ & $171.0 \pm 14.12 \mathrm{~b}$ & $278.15 \pm 20.87 b$ & $172.03 \pm 12.3^{c}$ & $266.38 \pm 18.15^{c}$ & $182.2 \pm 18.58 \mathrm{~d}$ & $274.15 \pm 27.8 \mathrm{~d}$ \\
\hline $\operatorname{ALT}(\mathrm{U} / \mathrm{L})$ & $32.08 \pm 0.51 \mathrm{a}$ & $33.62 \pm 1.48$ a & $36.57 \pm 2.39 \mathrm{~b}$ & $30.36 \pm 1.07 \mathrm{~b}$ & $34.35 \pm 1.11^{c}$ & $31.43 \pm 0.72 \mathrm{c}$ & $32.98 \pm 1.99 \mathrm{~d}$ & $28.68 \pm 0.42 \mathrm{~d}$ \\
\hline Total bilirubin (mg/dl) & $0.4 \pm 0.01$ a & $0.42 \pm 0.01^{\mathrm{a}}$ & $0.39 \pm 0.03 b$ & $0.42 \pm 0.03 b$ & $0.39 \pm 0.01^{c}$ & $0.41 \pm 0.01 \mathrm{c}$ & $0.4 \pm 0.02 \mathrm{~d}$ & $0.42 \pm 0.01 \mathrm{~d}$ \\
\hline Direct bilirubin (mg/dl) & $0.04 \pm 0.0$ a & $0.14 \pm 0.01 \mathrm{a}$ & $0.04 \pm 0.0 \mathrm{~b}$ & $0.15 \pm 0.01 b$ & $0.04 \pm 0.0 \mathrm{c}$ & $0.16 \pm 0.01^{c}$ & $0.04 \pm 0.0 \mathrm{~d}$ & $0.16 \pm 0.01 \mathrm{~d}$ \\
\hline $\begin{array}{l}\text { Indirect } \\
(\mathrm{mg} / \mathrm{dl})\end{array}$ & $0.36 \pm 0.01 \mathrm{a}$ & $0.28 \pm 0.01 \mathrm{a}$ & $0.36 \pm 0.03 b$ & $0.27 \pm 0.03 \mathrm{~b}$ & $0.35 \pm 0.01 \mathrm{c}$ & $0.26 \pm 0.01 \mathrm{c}$ & $0.36 \pm 0.01 \mathrm{~d}$ & $0.27 \pm 0.02 \mathrm{~d}$ \\
\hline
\end{tabular}


Table 6 Effects of IAD at different dose on blood glucose, lipid profile and kidney function parameters

\begin{tabular}{|c|c|c|c|c|c|c|c|c|}
\hline \multirow[b]{2}{*}{ Duration } & \multicolumn{2}{|l|}{ CONTROL } & \multicolumn{2}{|c|}{ IAD (8.15 MG/KG) } & \multicolumn{2}{|c|}{ IAD (16.3 MG/KG) } & \multicolumn{2}{|c|}{ IAD (32.6 MG/KG) } \\
\hline & $21 \mathrm{DAY}$ & 42 DAY & $21 \mathrm{DAY}$ & 42 DAY & $21 \mathrm{DAY}$ & 42 DAY & $21 \mathrm{DAY}$ & 42 DAY \\
\hline Glucose (mg/dl) & $216.43 \pm 4.78$ a & $213.6 \pm 2.37 \mathrm{a}$ & $225.4 \pm 12.37 \mathrm{~b}$ & $211.2 \pm 5.56^{b}$ & $232.22 \pm 8.94 \mathrm{c}$ & $216.13 \pm 2.14 \mathrm{c}$ & $240.78 \pm 13.5 \mathrm{~d}$ & $219.33 \pm 0.76^{d}$ \\
\hline Triacylglycerol (mg/dl) & $134.58 \pm 15.81$ a & $125.73 \pm 7.62$ a & $133.35 \pm 0.9 \mathrm{~b}$ & $127.25 \pm 5.29 b$ & $126.3 \pm 7.53^{c}$ & $129.15 \pm 2.61^{c}$ & $121.9 \pm 6.48 \mathrm{~d}$ & $132.58 \pm 1.29 \mathrm{~d}$ \\
\hline Cholesterol & $139.9 \pm 2.13$ a & $144.17 \pm 4.14 \mathrm{a}$ & $137.43 \pm 2.31 \mathrm{~b}$ & $140.45 \pm 4.64 b$ & $136.85 \pm 0.76^{c}$ & $142.4 \pm 5.17 \mathrm{c}$ & $134.5 \pm 1.36^{d}$ & $139.75 \pm 4.99 \mathrm{~d}$ \\
\hline HDL-C (mg/dl) & $34.13 \pm 0.72 \mathrm{a}$ & $34.13 \pm 0.72 \mathrm{a}$ & $35 \pm 1.23 \mathrm{~b}$ & $34.2 \pm 1.21 \mathrm{~b}$ & $42.5 \pm 1.07 \mathrm{c}$ & $43.23 \pm 1.11^{c}$ & $43.65 \pm 0.44 \mathrm{~d}$ & $46.65 \pm 1.49 \mathrm{~d}$ \\
\hline LDL-C (mg/dl) & $78.85 \pm 0.73 a$ & $84.89 \pm 4.35$ a & $75.76 \pm 1.51 b$ & $80.8 \pm 2.97 \mathrm{~b}$ & $69.09 \pm 1.21^{c}$ & $73.35 \pm 4.19 c$ & $66.47 \pm 2.33 \mathrm{~d}$ & $66.59 \pm 5.62 \mathrm{~d}$ \\
\hline VLDL-C (mg/dl) & $26.92 \pm 3.16^{a}$ & $25.145 \pm 1.52 \mathrm{a}$ & $26.67 \pm 0.18 \mathrm{~b}$ & $25.45 \pm 0.06^{b}$ & $25.26 \pm 1.51^{c}$ & $25.83 \pm 0.52^{c}$ & $24.38 \pm 1.3 \mathrm{~d}$ & $26.52 \pm 0.26^{d}$ \\
\hline Urea (mg/dl) & $14.09 \pm 0.9$ a & $13.56 \pm 1.55 \mathrm{a}$ & $14.05 \pm 0.76^{b}$ & $16.65 \pm 3.7 \mathrm{~b}$ & $14.53 \pm 0.2^{c}$ & $16.53 \pm 2.01^{\mathrm{c}}$ & $14.63 \pm 0.27 \mathrm{~d}$ & $14.83 \pm 2.29 \mathrm{~d}$ \\
\hline Creatinine (mg/dl) & $0.51 \pm 0.03 \mathrm{a}$ & $0.42 \pm 0.02 \mathrm{a}$ & $0.46 \pm 0.03 b$ & $0.36 \pm 0.01 \mathrm{~b}$ & $0.47 \pm 0.03 c$ & $0.35 \pm 0.02^{c}$ & $0.48 \pm 0.01 \mathrm{~d}$ & $0.40 \pm 0.02 \mathrm{~d}$ \\
\hline Uric acid (mg/dl) & $7.92 \pm 1.1$ a & $6.13 \pm 0.27 \mathrm{a}$ & $6.92 \pm 1.03 b$ & $5.27 \pm 0.08 b$ & $8.12 \pm 0.74 \mathrm{c}$ & $5.97 \pm 0.56 \mathrm{c}$ & $9.28 \pm 0.48 \mathrm{~d}$ & $6.94 \pm 0.24 \mathrm{~d}$ \\
\hline
\end{tabular}




\section{Discussion}

IAD is classified in the broadest sense as a biological response modifier and more specifically as an antiviral and immunomodulating agent, thereby enhancing the body's resistance against infections.Although the drug was developed as a substance which improves learning behaviour and learning ability. For a variety of indications IAD is registered and sold under a number of trade names as follows: Isoprinosine $\AA$, Isoprinosin $₫$, Imunovir $\AA$, Delimmun $\AA$, Viruxan $\AA$, Virimun $\AA$, Virustop $\AA$, Farviran $®$. Inosine Acedoben Dimepranol is mainly marketed as a tablet or syrup formulation [7].

As immunomodulatory, IAD has been reported to enhance cell mediated immunity, by stimulating the differentiation of $\mathrm{T}$ lymphocytes into T cytotoxic cells and T helper cells and increasing cytokine production. This assists the body to mount an effective defense. In addition, it increases the humoral immune response by stimulating the differentiation of B lymphocytes into plasmatic cells and by enhancing antibody production [8]. Moreover, IAD increases the production of IL-1, IL-2 and IF- $\gamma$. IAD also potentiates neutrophil, monocyte and macrophage chemotaxis and phagocytosis. [9].

As antiviral, IAD inhibits the replication of a number of viruses, including both the DNA and RNA types. In contrast to antimetabolites, it affects the translation process first. The drug increases the intranuclear transport of mRNA and stabilizes the complex ribosome-RNA, in this way impairing the genetic information code transmitted by the virus with a resulting "blockade" of the exogenous translation. In vivo, IAD enhances potentiation of depressed lymphocytic mRNA protein synthesis and translational ability while inhibiting viral RNA synthesis achieved by incorporation of inosinemediated orotic acid into polyribosomes and inhibition of polyadenylic acid attachment to viral messenger RNA; i.e the action of the drug is indirect contrary to that of other virucidal agents [10].

The present study was designed to evaluate the immunopotentiating potential of IAD in an important species that is broiler chickens, either vaccinated or unvaccinated; and to evaluate its safety profile after treatment with escalating doses.

Data of the present study revealed that day after day administration of IAD increased total and lymphocytic counts of broiler chicks on the days 21 and 42 . Such finding further increase upon combination with ND vaccine. Although there is no similar study conducted on chickens, yet this finding may be parallel to those reported in human by [11] who found that Inosiplex acts a stimulating agent for normal human T cells and human leukocytes.

Data of the present study showed that there was a significant increase in Mean $\log ^{2} \mathrm{HI}$ serum antibody titer of chicks received vaccine and vaccine + IAD on the day 42 of experiment if compared with the control and IAD only groups indicating the immunopotentiating effect of IAD when combined with ND vaccine. Parallel findings were reported by [8] in pigeon immunized against Paramyxovirus, where there were significant increases in antibody titers that were Isinoplex-dose dependent.

In challenge test, chickens treated with IAD either vaccinated or unvaccinated showed different degrees of protection when challenged post treatment by $0.5 \mathrm{ml} /$ bird of virulent viscerotropic velogenic NDV containing $10^{6} \mathrm{EID} 50 / \mathrm{ml}$, by I/M route. After 7 days of observation period, the challenged birds exhibited 25\% protection (IAD only), 50\% (vaccine only) and $75 \%$ (IAD + Vaccine). These findings indicate that IAD enhances natural immunity and potentiates specific immunity of the given vaccine as well. Although there is no similar study conducted on chickens, however, such finding may be parallel to those recorded from human volunteers with Rhino virus [12], children with Varicella zoster virus [13], , as well as in vitro [14].

Our findings of survival or protection could be explained on the basis of the significant decrements of NDV titer in IAD only, Vaccine only and IAD + Vaccine groups comparing with control group indicated by PCR. Despite absence of similar findings in chickens, yet decreasing other virus titers by Isoprinosine may be supportive findings of the present study; for instance, [15] and [16] found that treatment with Isoprinosine decreased HB and HC virus titers, respectively.

However, on the other hand, our findings may not be consistent with [17] who found that Isoprinosine does not protect against frequent respiratory tract infections in childhood.

Experiment-II of our study was designed to look at the safety profile of Isoprinosine. The data were found very promising where the drug did not adversely affect almost all organs and functions of the chicken body. 
Hemogram results revealed no significant changes in erythrocytic count or indices. While leukocytes showed leukocytosis associated with lymphocytosis as a mean of body defense mechanism. [18] reported that inclusion of inosine to stored blood for transfusion did not alter the oxygen affinity of hemoglobin, as well as there were no accumulation of ferrihemoglobin observed for 20 days.

Our findings on hemogram may be partially consistent with [19] who found that there were no significant differences in RBCs count haemoglobin and haematocrit values in those volunteers received inosiplex as compared to placebo. However, their findings were inconsistent regarding WBCs where they reported no significant difference in white blood cell count, unlike our finding of leukocytosis and lymphocytosis. This difference may be attributed to species and research environments.

Data of the present study demonstrate significant dose and time increases in total protein and globulins in chicks received comparing with control group on especially on the day 42 of the experiment. The data may be parallel with [20] who found increment of total protein in patients with subacute sclerosing panencephalitis being treated with Isoprinosine. The increment of total protein in the present study was dependent upon increased globulin amount without change in that of albumin. Increased globulin levels may come from lymphocytosis and increased activity of Bcells that contribute to the immunostimulant effect of IAD.

Data of the present study recorded no significant effects of IAD, even in largest dose used ( $23.6 \mathrm{mg} / \mathrm{kg}$ ) on liver function biomarkers, namely, AST, ALT and Bilirubin (total, direct and indirect) on both days 21 and 42 of the experiment-II. These findings give a good promise for IAD as a safe agent on chicks. The findings may be parallel to those of [19] who monitored liver function in volunteers with influenza virus infection and received inosiplex. Our finding may be also parallel with those of [21] who reported that serological and biochemical parameters of liver function remained stable during the period of their treatment from HBV with Isoprinosine. However, the data may be inconsistent with those of [22] who reported, at the end of the trial of treatment of chronic HCV, side effects of higher frequency of elevated serum ALT (GPT) levels in Isoprinosine-treated patients.

The possible altering effects of IAD on selected metabolic parameters were also monitored for the 42 days of the experiment. Data of the present study (tables 16 and 17 figures 15 and 16), demonstrate no significant effects of IAD $(8.15,16.3$ and $32.6 \mathrm{mg} / \mathrm{kg})$ on serum Glucose, TG, Cholesterol and Lipoproteins (HDL, LDL, VLDL). This may add a positive safe point to IAD in broiler chickens. Our findings may be supported by [23] who reported the roles of inosine products on glucose, insulin and lipid metabolism. The authors stated that the role of adenosine (an inosine product) in glucose homeostasis is attributed to its ability to regulate insulin secretion, glucose release and clearance, glycogenolysis, and glycogenesis, through its membrane receptors. Moreover, adenosine has been linked with lipid metabolism by augmenting insulin-mediated inhibition of lipolysis, and the subsequent increase in free fatty acids and glycerol levels. In addition, adenosine contributes in controlling liver cholesterol synthesis, consequently affecting plasma levels of cholesterol and triglycerides, and the amount of adipose tissue.

Regarding the possible adverse effects of IAD on kidney function parameters, data of the present study demonstrate no significant effects of IAD, even with the largest dose, on serum Urea, Creatinine and Uric acid on days 21 and 42 of experiment. Our findings may be parallel with those of [19] who found no significant differences in kidney function parameters in patients received treatment with Isoprinosine.

The data may partially inconsistent with [24] who found an increase in uric acid level in a trial for treatment of patients suffering from senile dementia with isoprinosine. [25] did not record any Isoprinosine-related abnormalities in terms of biochemical and hematological parameters in sub-acute toxicity tests applied on mice. No significant differences in body weight and organ weight between the control and isoprinsoine-treated groups were observed. The authors added that the maximum tolerable dose was $2000 \mathrm{mg} / \mathrm{kg}$ body weight of mice.

\section{Conclusion}

By the end of the study we concluded that, IAD enhanced both nonspecific and specific immune responses in broiler chicken, especially in vaccinated ones, in terms of increased antibody and decreased NDV titers in serum and tissues, indicated by HI and PCR, respectively. Regarding safety profile, IAD showed dose-dependent good safety profile in broiler chickens, including blood picture, organ function profile and metabolic parameters, indicated by biochemical analyses. 


\section{Compliance with ethical standards}

\section{Disclosure of conflict of interest}

No conflict of interest exist.

\section{Statement of ethical approval}

The study protocol was approved by the institutional ethics committee

\section{References}

[1] Schwabenbauer K and Rushton J. (2007).Veterinary services for poultry production. In Proceedings of the International Conference Poultry in the Twenty-first Century: avian influenza and beyond, held, 5-7.

[2] Njei B, Garg SK, Kenta-Bibi E, Zhao P and Kongnyuy EJ. (2013). Isoprinosine versus other antiviral drugs for chronic hepatitis B. status and date: New, published in (4).

[3] Apriasari ML. (2016). Methisoprinol as an immunomodulator for treating infectious mononucleosis. Dental Journal (Majalah Kedokteran Gigi) 49(1), 1-4.

[4] Georgala S, Katoulis AC, Befon A, Georgala K and Stavropoulos PG. (2006). Inosiplex for treatment of alopecia areata: a randomized placebo-controlled study. Acta dermato-venereologica, 86(5), 422-424.

[5] Thomas JA and Thomas MJ. (1993).New biologics: their development, safety, and efficacy. In Biotechnology and safety assessment, 1-22, Raven Press New York.

[6] Paget G and Barnes J. (1964). Evaluation of results: quantitative application in different species. Evaluation of drug activities: pharmacometrics 1, 161.

[7] Ewopharma International L. (2002). ISOPRINOSINE® Inosine Acedoben Dimepranol, Argentina: unpublished.

[8] Stenzel T, Tykałowski B, Śmiałek M, Kwiatkowska-Stenzel A and Koncicki A. (2011). 'The effect of different doses of methisoprinol on the percentage of CD4+ and CD8+ T lymphocyte subpopulation and the antibody titers in pigeons immunised against PPMV-1', Polish journal of veterinary sciences, 14(3), 367-371.

[9] Petrova M, Jelev D, Ivanova A and Krastev Z. (2010). 'Isoprinosine affects serum cytokine levels in healthy adults', Journal of Interferon \& Cytokine Research, 30(4), 223-228.

[10] Ohnishi H, Kosuzume H, Inaba H, Ohkura M, Shimada S and Suzuki Y. (1983). 'The immunomodulatory action of inosiplex in relation to its effects in experimental viral infections', International journal of immunopharmacology, 5(3), 181-196.

[11] Wybran J, Govaerts A and Appelboom T. (1978). 'Inosiplex, a stimulating agent for normal human T cells and human leukocytes', The Journal of Immunology, 121(3), 1184-1187.

[12] Waldman RH and Ganguly R. (1977). 'Therapeutic efficacy of inosiplex (Isoprinosine $®$ ) in rhinovirus infection', Annals of the New York Academy of Sciences, 284(1), 153-160.

[13] Feldman S and Loft L. (1987). 'Varicella in children with cancer: impact of antiviral therapy and prophylaxis', Pediatrics, 80(4), 465-472.

[14] Nakamura T, Miyasaka N, Pope R, Talal N and Russell I. (1983). 'Immunomodulation by isoprinosine: effects on in vitro immune functions of lymphocytes from humans with autoimmune diseases', Clinical and experimental immunology, 52(1), 67.

[15] Krastev Z, Nikolova N, Jelev D, Antonov K and Mateva L. (2015). 'Inosine pranobex (Isoprinosine)-a potential adjuvant in the management of chronic HBV infection', MedInform, 2(1), 86-97.

[16] Nikolova N, Antonov K, Mateva L and Krastev Z. (2014). 'Could Inosine pranobex and Ribavirin in combination restore immune competence in chronic HCV advanced liver disease?', MedInform, 1, 35-44.

[17] Litzman J, Lokaj J, Krejčí M, Pešák S and Morgan G. (1999). 'Isoprinosine does not protect against frequent respiratory tract infections in childhood', European journal of pediatrics, 158(1), 32-37.

[18] Bunn HF, May MH, Kocholaty WF and Shields CE. (1969). 'Hemoglobin function in stored blood', The Journal of clinical investigation, 48(2), 311-321. 
[19] Khakoo RA, Watson GW, Waldman RH and Ganguly R. (1981). 'Effect of inosiplex (Isoprinosine®) on induced human influenza A infection', Journal of Antimicrobial Chemotherapy, 7(4), 389-397.

[20] Huttenlocher PR and Mattson RH. (1979). 'Isoprinosine in subacute sclerosing panencephalitis', Neurology, 29(6), 763-763.

[21] Cianciara J, Laskus T, Gabinska E and Loch T. (1990). 'Isoprinosine in the treatment of chronic active hepatitis type B', Scandinavian journal of infectious diseases, 22(6), 645-648.

[22] Pár A, Beró T, Brasch G, Gógl A, Kamarás G, Méhesfalvi E, Ozsvár Z, Paál M, Szipöcs I and Telegdy L. (1993). 'Isoprinosine therapy in chronic hepatitis C (multicenter placebo-controlled double-blind prospective study)', Orvosi hetilap, 134(19), 1015-1019.

[23] Koupenova M and Ravid K. (2013). 'Adenosine, adenosine receptors and their role in glucose homeostasis and lipid metabolism', Journal of cellular physiology.

[24] March J, Field J, Shanley J and Turner WJ. (1973). 'Biochemical observations during a trial of inosiplex in senile dementia', Journal of the American Geriatrics Society, 21(8), 372-378.

[25] Bhandary BSK, Sharmila K, Kumari NS, Bhat VS and Fernandes R. (2017). 'Acute and Subacute Toxicity Profile of Asparagus racemosus root extract, Isoprinosine and Shatvari Syrup in Swiss Albino Mice', Journal of Applied Pharmaceutical Science Vol, 7(05), 129-135.

\section{How to cite this article}

Abdel Maksoud H, Omnia MA and Mahmoud K. (2019). Biochemical study on immunomodulating and safety margin of inosine acedoben dimepranol before and after vaccination. GSC Advanced Research and Reviews, 1(1), 17-25. 